\title{
The rare Scottish endemic Hieracium fu/vocaesium Orange-flowered Hawkweed (Asteraceae) is on the verge of extinction
}

\author{
Timothy C. G. Rich \\ Cardiff, U.K.
}

\section{Corresponding author: tim rich@sky.com}

This pdf constitutes the Version of Record published on $26^{\text {th }}$ July 2021

\begin{abstract}
The rare Scottish endemic Hieracium fulvocaesium Pugsley, Orange-flowered Hawkweed, is on the verge of extinction. Historic records indicate it was only known from the east banks of the River Naver, Bettyhill, Sutherland. Three plants were rediscovered in 2017. It is IUCN threat status 'Critically Endangered' and it requires urgent conservation work to conserve it in the wild.
\end{abstract}

Keywords: IUCN threat status; Bettyhill; Scotland.

\section{Introduction}

The rare Scottish endemic Hieracium fulvocaesium Pugsley, Orange-flowered Hawkweed, is on the verge of extinction. It was first collected at Bettyhill, Sutherland by F. J. Hanbury in 1886 (BM), and further material was collected over the next few years including numerous specimens on 30 August 1888 which were distributed as $H$. orarium Lindeb. as part of the Set of British Hieracia no. 93 (Hanbury, 1888). It was described by Hanbury (1894) as H. orarium var. fulvum F. Hanb. and was raised to species status as H. fulvocaesium by Pugsley (1941). It is accepted as a species in the current British Hieracium monograph (Sell \& Murrell, 2006).

Hieracium fulvocaesium is a distinctive member of Hieracium section Vulgata (Figs. 1 and 2). It is characterised by the basal rosette and 2-4 stem leaves which are weakly glaucous, strongly toothed and glabrous above, the small capitula with noticeably short ligules, and the involucral bracts with dense stellate hairs and numerous simple and glandular hairs. The styles are yellow when fresh but discolour orangey when dry. Hanbury (1894) described the flowers as small and reddishyellow; observations in 2017 and in cultivation since indicate the ligules are definitely short and densely arranged but are not clearly different in colour to other hawkweeds. In cultivation the plant tends to become gross with deeply toothed leaves (BM, CGE).

The aim of this paper is to summarise the information known about $H$. fulvocaesium and to draw attention to its precarious state in the wild. 


\section{Methods}

Records were extracted from herbaria (BM, CGE, E, MNE, NMW; in total 38 specimens determined by P. D. Sell or D. McCosh) and D. McCosh's Hieracium database (2016 version). Some labels of cultivated material in CGE have slightly different details to the wild-collected material; only the latter are cited here. Some duplicate herbarium material is not labelled as cultivated.

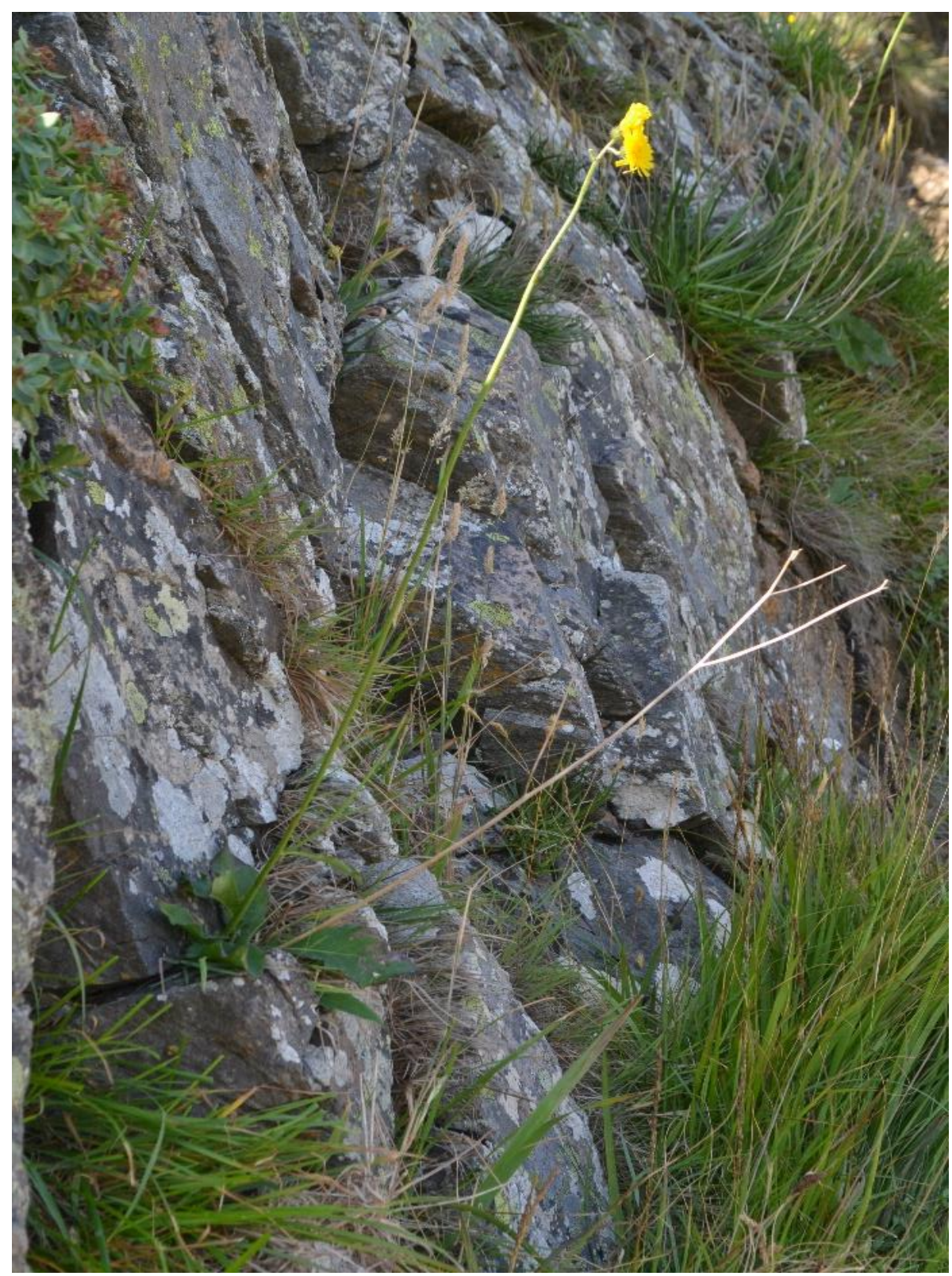

Figure 1. Hieracium fulvocaesium plant, Bettyhill, 2017. 

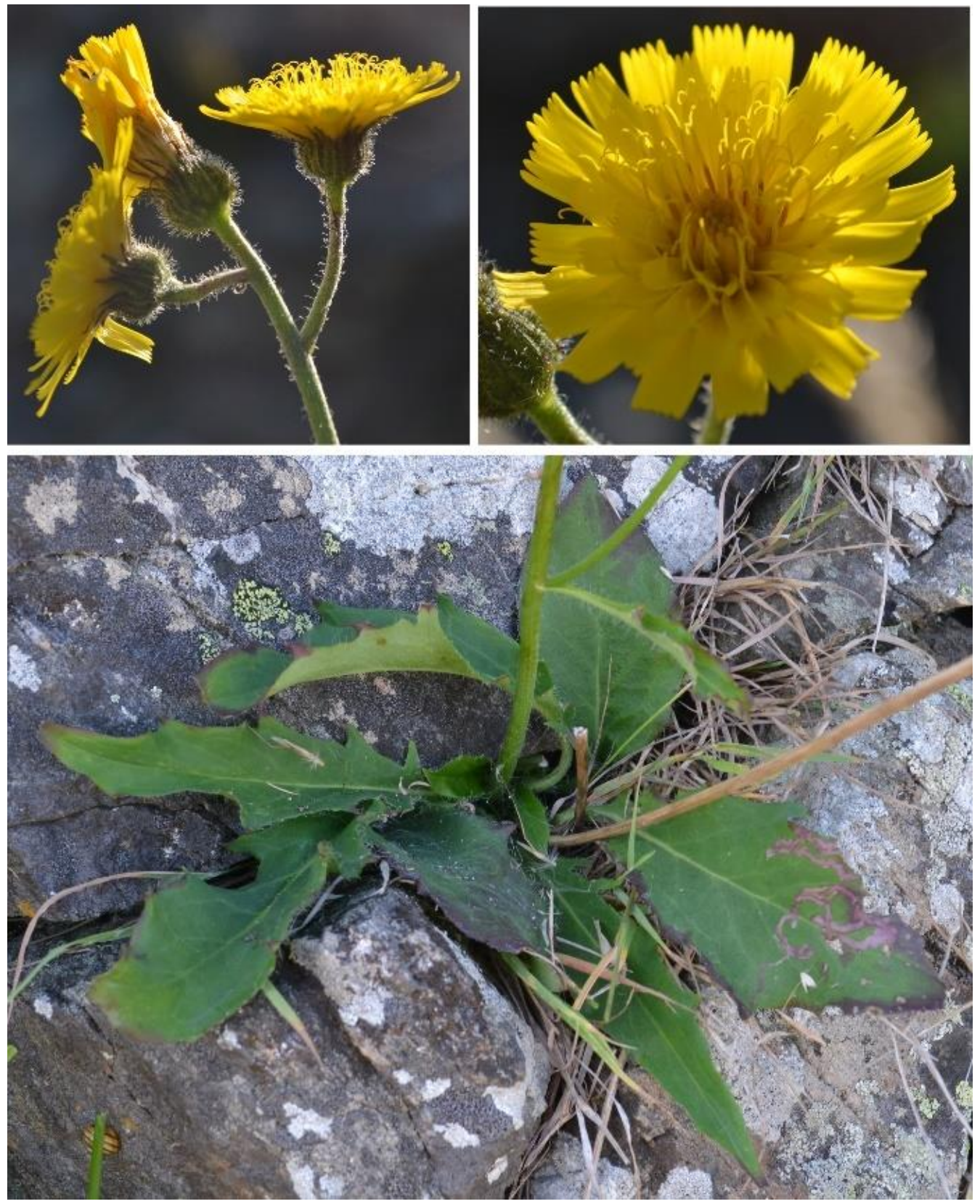

Figure 2. Details of $\boldsymbol{H}$. fulvocaesium, Bettyhill, 2017.

The historic records were used to direct the field surveys. Both sides of the River Naver were searched from Torrisdale Bay to Invernaver on four days in August 2016 and July and August 2017. Only one approximate 6-figure grid reference for a site was available and 1968 specimens cultivated from material collected in 1953 by J. E Raven had a grid reference of NV6962 added (the original specimen lacked a grid reference).

\section{Results}

The historic records traced are listed in Table 1 . These show it has only been collected from the east banks of the River Naver at Bettyhill during two short periods; in the early days of exploration of the rich hawkweed flora of the north coast of Scotland in 1886-1888, and in 1952-1953. 
Table 1. Historic records of Hieracium fulvocaesium from Bettyhill. Cultivated material is not included.

\begin{tabular}{|l|l|l|l|}
\hline Locality & Date & Collector & Source \\
\hline East bank of Naver & 12 July 1886 & F. J. Hanbury & BM \\
\hline East bank of Naver & 25 July 1887 & F. J. Hanbury & BM \\
\hline East bank of Naver & 25 July 1888 & J. C. Melvill & CGE \\
\hline East bank of Naver & 25 July 1888 & F. J. Hanbury & BM \\
\hline Bettyhill & $\begin{array}{l}30 \text { August } \\
1888\end{array}$ & $\begin{array}{l}\text { E. F. \& W. R. } \\
\text { Linton }\end{array}$ & $\begin{array}{l}\text { BM, CGE, E; Set of } \\
\text { British Hieracia no. } 93 \\
\text { H. orarium. }\end{array}$ \\
\hline Banks of Naver & 20 June 1952 & J. E. Raven & Herb. D. McCosh \\
\hline Banks of Naver & 27 June 1952 & J. E. Raven & CGE \\
\hline Bettyhill, NC703616 & July 1953 & $\begin{array}{l}\text { J. W. Cardew } \\
\text { \& C. West }\end{array}$ & MNE \\
\hline Banks of Naver & 31 August & J. E. Raven & E \\
\hline
\end{tabular}

Marshall \& Shoolbred (1898) reported H. fulvocaesium from Melness Sands "in profusion over a small area. This is a beautiful plant with deep orange-yellow blossoms and very yellow foliage"; these records refer to $H$. proximum $F$. Hanb. Records cited by Linton (1905) also refer to $H$. proximum and perhaps $H$. angustatum (Lindeb.) Lindeb.

In 2017 at the third attempt, three plants of $H$. fulvocaesium were found near Bettyhill, possibly at the site where J. Raven collected it in 1953. Two plants were in flower, one of which still had last year's stem showing it had also flowered in 2016. There was one vegetative rosette and two possible seedlings. The plants were rooted on a south-facing rock of Bettyhill Formation bedrock, about 1-2 m above high tide level and were associated with Avenula pubescens, Dactylis glomerata, Festuca rubra, Holcus lanatus, Molinia caerulea, Plantago lanceolata, Polygala vulgaris and Rhodiola rosea. At least five other Hieracium species occurred in the vicinity. The area was lightly grazed by sheep, which could have easily reached and eaten the plants. Full details have been deposited with the Millennium Seed Bank (Rich, 2018) and Scottish Natural Heritage; one leaf and one capitulum have been deposited in $\mathbf{K}$ as a voucher.

No plants were found elsewhere along the River Naver and there were no obvious rock outcrops or open slopes on which the hawkweed could have occurred. On the east bank north of the pier, the banks at the top of the saltmarsh were walled with a few low rocks periodically grazed by sheep. Above the walls, the soft low cliffs have long and rank or occasionally grazed grassland with a few small rock outcrops and scrub or small conifer plantations. No plants were found on banks at or near the 1953 grid reference which is now dense, rank grassland, possibly modified by fertiliser from the fields above. The western banks of the Naver are low, open and heavily grazed and unsuitable for hawkweeds, though a range of species were found on rocks and cliffs behind. Brian Burrow has also looked for $H$. fulvocaesium in the Naver area on several occasions, once with Vincent Jones, without success (pers. comm. 2017). 


\section{Discussion}

The tiny population of three plants is extremely vulnerable to sheep grazing, sea level rise, slumping of soft sea cliff sediments and sea pollution events, and the plant is in imminent danger of extinction in the wild. The IUCN (2001) threat status is 'Critically Endangered' based on the occurrence of only two mature plants in one location and an assessment of a high risk of extinction in the near future.

Hieracium fulvocaesium requires urgent attention for conservation in the wild and requires a conservation action plan to be compiled, funded and implemented. Neither the plant not the site has any statutory protection (the population is outside the Invernaver Site of Special Scientific Interest as it is above the high tide line). Seeds were collected with consent from the landowner and deposited in the Millennium Seed Bank for ex situ conservation.

Based on the numerous specimens collected in 1888, it may at one time have been at least locally frequent (Pugsley, 1948, noted it was collected 'in some abundance'). It is difficult to know how widespread it once was along the Naver; it has gone from the only localised site and has declined nearly towards extinction.

\section{Acknowledgements}

I thank Sarah Bird, Brian Burrow and David McCosh for their help and the Keepers for access to herbaria. The collection of seed was funded by the Esmée Fairbairn Foundation as part of the UK Flora Project at the Millennium Seed Bank.

\section{References}

Hanbury, F.J. 1888. Notes on some Hieracia new to Britain. Journal of Botany 26: 204-206.

Hanbury, F.J. 1894. Notes on British Hieracia. Journal of Botany 32: 225-233.

IUCN 2001. IUCN Red list categories and criteria. Version 3.1. Gland: International Union for Conservation of Nature.

Linton, W.R. 1905. An account of the British Hieracia. London: West, Newman \& Co.

Marshall, E.S. \& Shoolbred, W.A. (1898). Notes of a tour in N. Scotland, 1897. Journal of Botany 36: 166-177.

Pugsley, H.W. 1941. New species of Hieracium in Britain. Journal of Botany 79: 177197.

Pugsley, H.W. 1948. A Prodromus of the British Hieracia. Journal of the Linnean Society of London (Botany) 54: 1-356.

Rich, T.C.G. 2018. Millennium Seed Bank UK Flora Project. Seed collecting report for 2016-2017. Unpublished report to Royal Botanic Gardens, Kew.

Sell, P.D. \& Murrell, G. 2006. Flora of Great Britain and Ireland. Volume 4. Cambridge: Cambridge University Press.

Copyright retained by author(s). Published by BSBI under the terms of the Creative Commons Attribution 4.0 International Public License.

ISSN: $2632-4970$

https://doi.org/10.33928/bib.2021.03.183 